УДК 631.51(011+012+013)+519.237

(C) 2016

Цьова Ю. А., здобувач

(науковий керівник - доктор сільськогосподарських наук, професор П. В. Писаренко)

Полтавська державна аграрна академія

\title{
ДИСКРИМІНАНТНИЙ АНАЛІЗ АГРОЕКОЛОГІЧНОГО ВПЛИВУ СПОСОБІВ МЕХАНІЧНОГО ОБРОБІТКУ ГРУНТУ
}

\section{Рецензент - доктор біологічних наук О. В. Жуков}

У статті представлено результати дискримінантного аналізу за едафічними показниками станів грунтової системи, які формуються внаслідок різних способів механічного обробітку. Показано, щчо для дискримінації чизелювання, безполицевого та мінімального обробітку, а також «нульового обробітку» достатньо дві канонічні дискримінантні осі. Канонічна функиія 1 дискримінує способи механічного обробітку з високою глибиною оранки та способи з малою глибиною та нульовим обробітком. Канонічна функція 2 дискримінує кожну з перших груп на підгрупи з меншою глибиною оранки у парі. Більш глибокі варіанти оранки відрізняються більшими рівнями поживних речовин (азот, фосфор, калій). Значення канонічних змінних розглядаються як маркери осей простору, в межах якого відбивається мінливість едафічних показників.

Ключові слова: механічний обробіток, трунт, дискримінантний аналіз, едафічні властивості.

Постановка проблеми. Розробка і впровадження ресурсозберігаючих технологій $\epsilon$ одним із напрямів ефективного господарювання та збереження довкілля [11]. У загальних витратах матеріально-технічних ресурсів, що використовуються в рослинницькій галузі, майже $40 \%$ припадає на долю паливо-мастильних матеріалів, тому скорочення їх витрат набуває першочергового значення. У технологіях вирощування сільськогосподарських культур найбільші резерви енергозбереження мають способи обробітку грунту із запровадженням безполицевого і мінімального обробітку шляхом використання грунтообробних знарядь, новітніх конструкцій та вдосконалення вже відомих до цього землеробам [23]. Однак зменшення активного впливу на поверхню грунту послаблює кругообіг поживних елементів, що, з одного боку, сприяє збереженню родючості, з іншого, - зниженню продуктивності ріллі через відому «скупість гумусу». Посилання на необхідність ресурсозбереження та підвищення економічної ефективності в даному випадку не завжди виправдані через високу суб'єктивність даної оцінки. Зниження ж урожайності культур після скасування інтенсивного обробітку часто $є$ головним стримуючим фактором впровадження мінімальних технологій [22].

Характер впливу різних способів механічного обробітку грунту на едафічні показники $є$ актуальною проблемою, яка потребує свого вирішення.

Аналіз останніх досліджень і публікацій, у яких започатковано розв'язання проблеми. Способи обробітку грунту впливають на агрегатну структуру грунту [8]. Родючість грунтів, особливо важких за гранулометричним складом, великою мірою залежить від структури, яка визначає їх повітряний, водний, поживний та інші режими [6]. Безполицевий (плоскоріз) обробіток сприяє накопиченню вологи в грунті $[2,9,15,20]$.

Способи обробітку впливають і на інші властивості грунту, зокрема на щільність. Більшість дослідників дійшли висновку, що щільність грунту підвищується в разі застосування поверхневих основних обробок до $0,94-1,26$ г/ $\mathrm{cm}^{3}$, тоді як за відвальної і безвідвальної обробках вона нижча $0,86-1,17 \Gamma / \mathrm{cm}^{3}[3,13,19]$. Водночас $\epsilon$ й інші висновки. Об'ємна маса грунту істотно не розрізняється залежно від вживаних обробок, оскільки коливання щільності грунту знаходяться в оптимальних межах для зростання сільськогосподарських культур. У доказ приведемо дані багаторічного досвіду, проведеного І. П. Талановым [17]. Заміна щорічної оранки мілким або плоскорізним обробітком не привели до надмірного розущільнення грунту.

Способи обробітку по-різному впливають на мікрофлору грунту. Це відбувається в основному завдяки зміні щільності і режиму вологості грунту $[10,16,21]$. Встановлено, що тривале застосування безполицевих способів обробітку грунту призводить до диференціації орного шару, збільшенню біологічної активності його верхньої та зниженню нижньої частини $[4,12,14,18]$.

Отже, різні способи механічного обробітку грунту впливають на комплекс властивостей грунту та на перебіг їх динаміки. Для переважної більшості досліджень властивий методичний підхід, за якого досліджується окремий показник або сукупність споріднених показників та вплив 
на них різних систем обробітку грунту.

Мета дослідження. У рамках системного підходу запропонувати процедуру, за допомогою якої можна встановити місце тієї або іншої системи обробітку грунту в багатовимірному просторі, яке визначається складною сукупністю едафічних показників як індикаторів стану агроекосистеми.

Матеріали та методи дослідження. Польові дослідження проводились у тривалому досліді, закладеному в 2010-2015 рр. у приватному сільськогосподарському підприємстві «Нива» Шишацького району, Полтавської області, лабораторно-аналітичні - на базі Полтавського центру «Облдержродючість», с. Степне та на кафедрі землеробства і агрохімії ім. В. І. Сазанова Полтавської державної аграрної академії.

Дослідження проводились у ланці сівозміни: кукурудза на зерно (Піонер ПР38Р92) - ячмінь ярий (Командор Р2) - горох (сорт Мадонна). Дослід включає наступні варіанти технологій (ix елементи):

1. Традиційна, яка базується на різноглибинній оранці на 27-30 см;

2. Глибокий обробіток без перевертання скиби чизельними глибокорозпушувачами на 40 см;

3. Грунтозахисна 3 мінімальним обробітком на глибину 4-5 см;

4. Технологія прямого висіву без обробітку грунту (нульовий обробіток або No-till).

Уміст загального гумусу встановлено за методом Тюріна в модифікації Сімакова (ДСТУ 4289:2004). Вміст нітратного азоту визначено за допомогою іонселективного електроду, амонійного азоту - за допомогою реактиву Несслера, вміст рухомих сполук фосфору та калію - в одній витяжці за методом Чирікова в модифікації ЦІНАО з наступним визначенням фосфору фотометрично за методом Деніже, калію - на полуменевому фотометрі [1].

Дискримінантний аналіз проведений за допомогою програми Statistica 7.0.

Результати досліджень. Динаміка агроекологічних показників може визначатися як наслідок впливу того чи іншого способу обробітку грунту, так і екологічними факторами іншої природи.
Для встановлення специфіки впливу способів обробітку грунту ми пропонуємо застосувати дискримінантний аналіз. Ця техніка належить до класифікаційних процедур 3 навчанням [7], тобто має на меті знайти математичні правила, які найкращим чином дали б змогу розрізнити (дискримінувати) категоріальні змінні або якісні стани системи.

Такими станами $є$ способи механічного обробітку грунту, а предикторами виступають едафічні показники. Завдання ставиться так, що треба знайти правила для визначення того способу механічного обробітку, який було застосовано за едафічними показниками, які встановилися у результаті такого впливу.

У дискримінантному аналізі виокремлюються так звані канонічні змінні, які найкращим чином здатні розрізнити досліджувані категоріальні стани системи.

Нами був проведений $\chi^{2}$-тест для визначення кількості значущих канонічних змінних (табл. 1).

Перший рядок таблиці надає критерій статистичної значимості для усіх коренів. Оскільки рівень значимості менший за 0,05 , то існує хоча $б$ один канонічний корінь, який $є$ статистично значущим. Другий рядок характеризує значимість коренів, які залишаться після видалення першого. Оскільки $p$-рівень менший за 0,05 , то серед тих коренів, що залишилися, є статистично значущі. В разі видалення другого кореня значущих канонічних коренів більше не залишилось. Отже, для дискримінації способів механічного обробітку грунту за їх впливом на динаміку грунтових властивостей можуть бути застосовані два канонічних кореня.

Природу цих канонічних коренів можна дослідити за кореляцію зі зміннимипредикторами (табл. 2). Одержані результати свідчать про те, що найважливішими для диференціації способів механічного обробітку грунту є такі едафічні показники, як уміст гумусу, азоту, фосфору та калію, а також похідні від них нелінійні змінні - $[\mathrm{pH}]^{2},\left[\mathrm{P}_{2} \mathrm{O}_{5}\right]^{2},[\mathrm{pH}] \cdot\left[\mathrm{P}_{2} \mathrm{O}_{5}\right]$, $[\mathrm{pH}] \cdot\left[\mathrm{K}_{2} \mathrm{O}\right]$.

\section{1. $\chi^{2}$-тест для видалених коренів}

\begin{tabular}{|c|c|c|c|c|c|c|}
\hline $\begin{array}{c}\text { Видалені } \\
\text { корені }\end{array}$ & $\begin{array}{c}\text { Власне } \\
\text { значення }\end{array}$ & $\begin{array}{c}\text { Канонічне } \\
\mathrm{R}\end{array}$ & $\begin{array}{c}\text { Лямбда } \\
\text { Уілкса }\end{array}$ & $\chi^{2}$ & $\begin{array}{c}\text { Ступені } \\
\text { волі }\end{array}$ & $\begin{array}{c}p \text { - } \\
\text { рівень }\end{array}$ \\
\hline 0 & 0,59 & 0,61 & 0,50 & 166,41 & 60 & 0,00 \\
\hline 1 & 0,16 & 0,38 & 0,79 & 55,18 & 38 & 0,04 \\
\hline 2 & 0,08 & 0,27 & 0,92 & 18,74 & 18 & 0,41 \\
\hline
\end{tabular}


Канонічна функція 1 диференціює способи обробітку грунту за впливом на загальний вміст факторів родючості (всі поживні речовини та гумус).

Канонічна функція 2 чутлива до вмісту в грунті комплексу NPK.

Також ця функція чутлива до корегуючого впливу рН та взаємодії окремих поживних речовин.

За едафічними показниками можна вірно ідентифікувати спосіб механічного обробітку грунту в 56,75 \% випадків (табл. 3).

Слід відзначити, що за випадкової альтернативи цей показник становив би $25 \%$.

Найбільшою специфічністю характеризується вплив чизелювання (70,00 \% вірних класифікацій), а найменшою - оранка на глибину 25-27 см
(48,33 вірних класифікацій).

Нульовий обробіток найближчий до грунтозахисного обробітку та оранки на глибину 25-27 cм, грунтозахисний обробіток - до нульового обробітку, оранка на глибину 25-27 см - до чизелювання та навпаки.

Центроїди для кожного типу обробітку грунту можна розмістити у просторі перших двох канонічних функцій (рис. 1).

Центроїд - це найтиповіше місце для даного категоріального об'єкту в межах простору дискримінантних функцій.

Чим ближче місцеположення реального об'єкту в просторі канонічних функцій до відповідного центроїда, тим з більшою впевненістю ми можемо його класифікувати як такий, що належить до відповідної категорії.

\section{2. Кореляція дискримінантних функцій з едафічними змінними}

\begin{tabular}{|c|c|c|c|c|}
\hline \multirow{2}{*}{ Змінні } & \multicolumn{4}{|c|}{ Дискримінантні функції } \\
\hline & 1 & 2 & 3 & $p$-рівень \\
\hline \multicolumn{5}{|c|}{ Лінійні змінні } \\
\hline Гумус (G) & $-0,52$ & 0,08 & 0,01 & 0,00 \\
\hline Кислотність (pH) & $-0,07$ & 0,09 & $-0,46$ & 0,42 \\
\hline Азот $(\mathrm{N})$ & $-0,14$ & $-0,28$ & 0,27 & 0,05 \\
\hline Фосфор (P) & $-0,20$ & $-0,38$ & $-0,15$ & 0,00 \\
\hline Калій (К) & $-0,22$ & $-0,52$ & 0,01 & 0,00 \\
\hline \multicolumn{5}{|c|}{ Нелінійні змінні } \\
\hline $\mathrm{G}^{\wedge} 2$ & $-0,07$ & 0.17 & $-0,14$ & 0,55 \\
\hline $\mathrm{pH}^{\wedge} 2$ & $-0,03$ & 0.08 & $-0,41$ & 0,05 \\
\hline $\mathrm{N}^{\wedge} 2$ & $-0,13$ & $-0,29$ & 0,29 & 0,78 \\
\hline $\mathrm{P}_{2} \mathrm{O}_{5} \wedge 2$ & -0.20 & $-0,32$ & -0.19 & 0,05 \\
\hline $\mathrm{K}_{2} \mathrm{O}^{\wedge} 2$ & $-0,24$ & $-0,46$ & 0,01 & 0,20 \\
\hline $\mathrm{G}^{*} \mathrm{pH}$ & $-0,08$ & 0,21 & $-0,42$ & 0,58 \\
\hline $\mathrm{G}^{*} \mathrm{~N}$ & $-0,13$ & $-0,13$ & 0,13 & 0,46 \\
\hline $\mathrm{G}^{*} \mathrm{P}$ & $-0,20$ & $-0,31$ & $-0,19$ & 0,66 \\
\hline$G^{*} \mathrm{~K}$ & $-0,24$ & $-0,49$ & $-0,04$ & 0,75 \\
\hline $\mathrm{pH}^{*} \mathrm{~N}$ & $-0,18$ & $-0,27$ & 0,11 & 0,23 \\
\hline $\mathrm{pH}^{*} \mathrm{P}$ & $-0,22$ & $-0,39$ & $-0,23$ & 0,01 \\
\hline $\mathrm{pH}^{*} \mathrm{~K}$ & $-0,23$ & $-0,50$ & $-0,04$ & 0,01 \\
\hline $\mathrm{N}^{*} \mathrm{P}$ & $-0,25$ & $-0,47$ & $-0,05$ & 0,09 \\
\hline $\mathrm{N}^{*} \mathrm{~K}$ & $-0,24$ & $-0,54$ & 0,11 & 0,11 \\
\hline $\mathrm{P}^{*} \mathrm{~K}$ & $-0,24$ & $-0,44$ & $-0,09$ & 0,14 \\
\hline
\end{tabular}


СТОРІНКА МОЛОДОГО ВЧЕНОГО

3. Класифікаційна матриця якості класифікації способів обробітку трунту за едафічними показниками

\begin{tabular}{|c|c|c|c|c|c|}
\hline \multirow{2}{*}{$\begin{array}{c}\text { Способи } \\
\text { обробітку }\end{array}$} & \multirow{2}{*}{$\begin{array}{c}\text { \% вірних } \\
\text { класифікацій }\end{array}$} & \multicolumn{4}{|c|}{ Результати класифікації } \\
\cline { 3 - 6 } & No-till $p=0,29$ & $\begin{array}{c}\text { Till_25_27 } \\
p=0,24\end{array}$ & Till_40 $p=0,24$ & Till_4_6 p $=0,24$ \\
\hline No-till & 52,78 & 38 & 13 & 9 & 12 \\
\hline Till_25_27 & 48,33 & 11 & 29 & 15 & 5 \\
\hline Till_40 & 70,00 & 2 & 13 & 42 & 3 \\
\hline Till_4_6 & 56,67 & 13 & 5 & 8 & 34 \\
\hline Усього & 56,75 & 64 & 60 & 74 & 54 \\
\hline
\end{tabular}

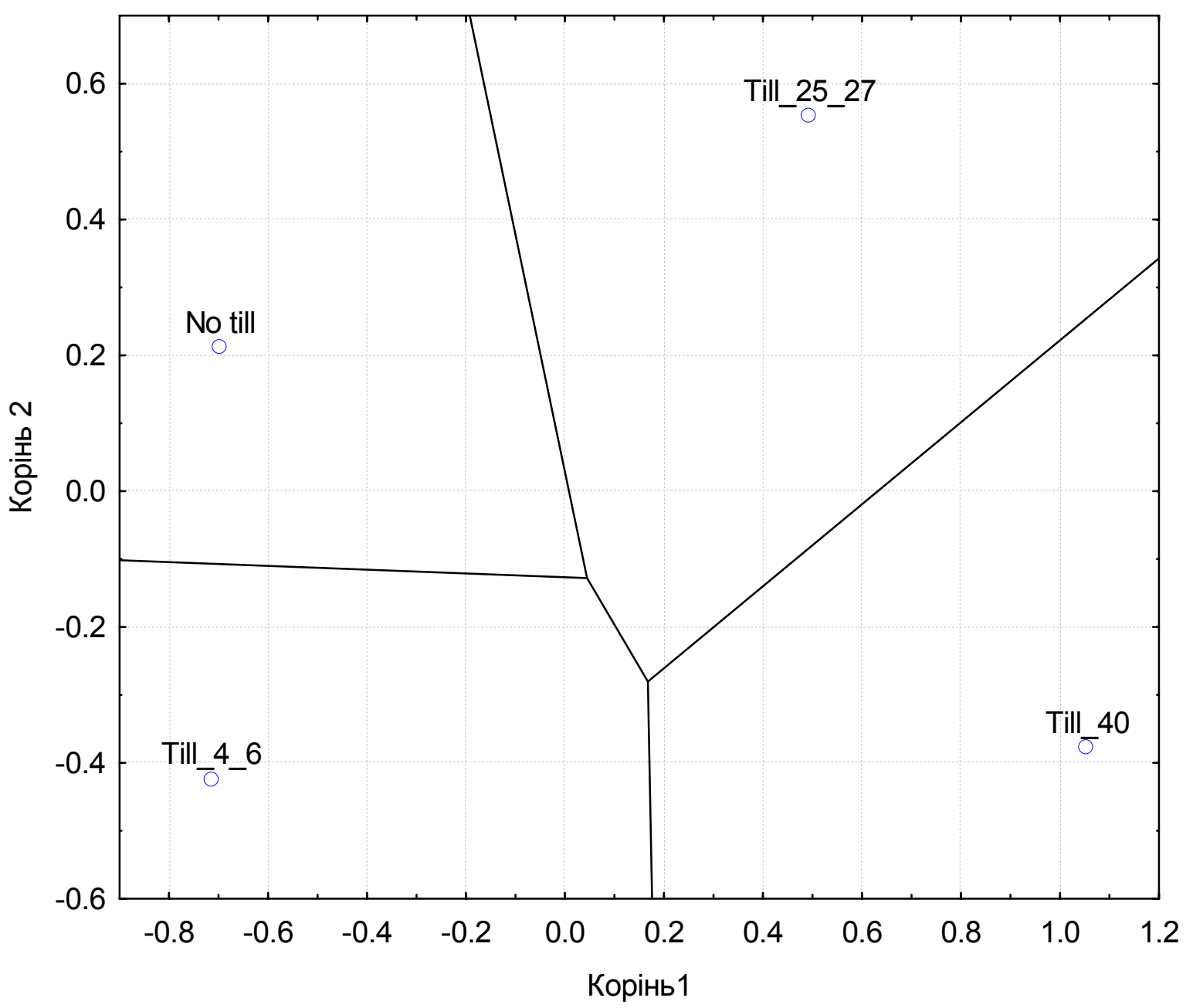

Рис. 1. Діаграма Вороного для центроїдів способів механічного обробімку трунту в просторі канонічних коренів

Тому топологію дискримінантного простору можна відобразити за допомогою діаграм Вороного. Границі між кожною парою центроїдів проводяться як сукупність точок, рівновіддалених від цих центроїдів. Тобто, якщо точка знаходиться у межах відповідного ареалу, то іiі можна віднести до відповідної категорії [5, 7].

Окрім того, топологія простору дискримінантних (канонічних) функцій можливо змістовно інтерпретована. Так, канонічна функція 1 розділяє способи механічного обробітку з високою глибиною оранки (чизелювання на глибину 40 см та оранка на глибину 25-27 см) від способів з малою глибиною та нульовим обробітком. Отже, глибокий механічний обробіток призводить до дегуміфікації та зменшення вмісту поживних речовин в грунті. 

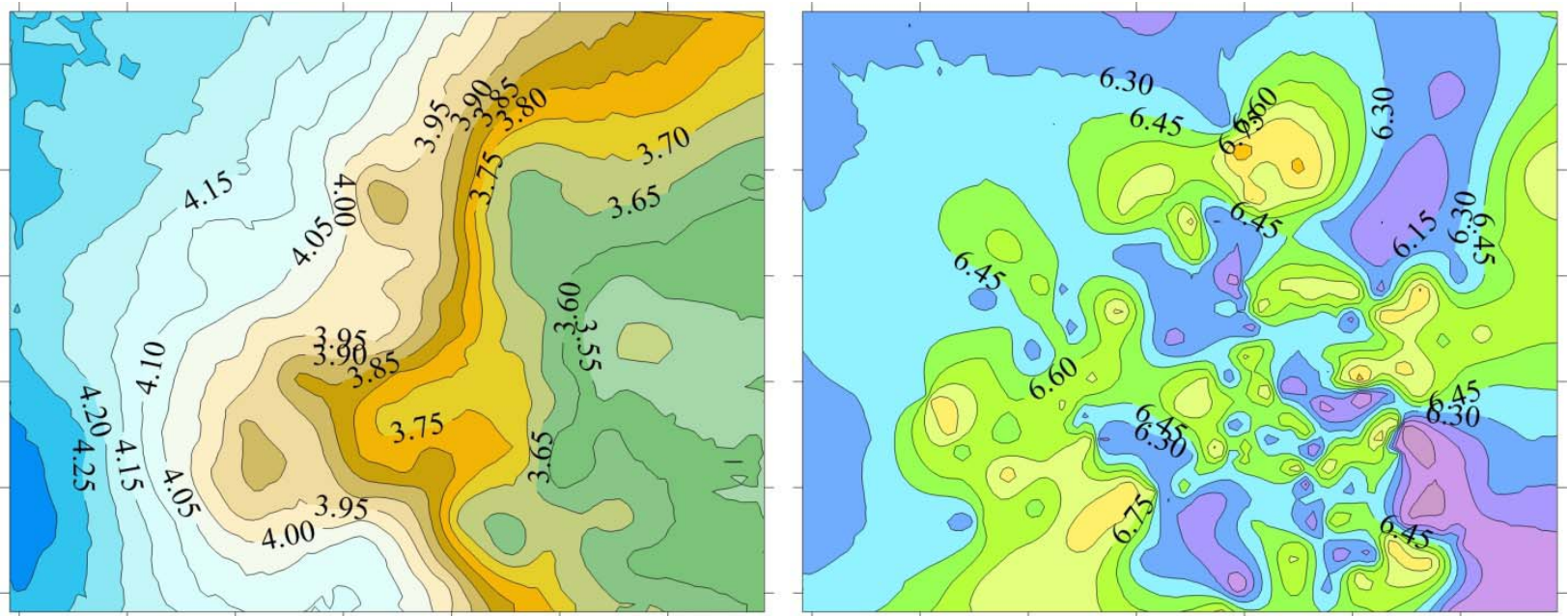

Гумус

$\mathrm{pH}$
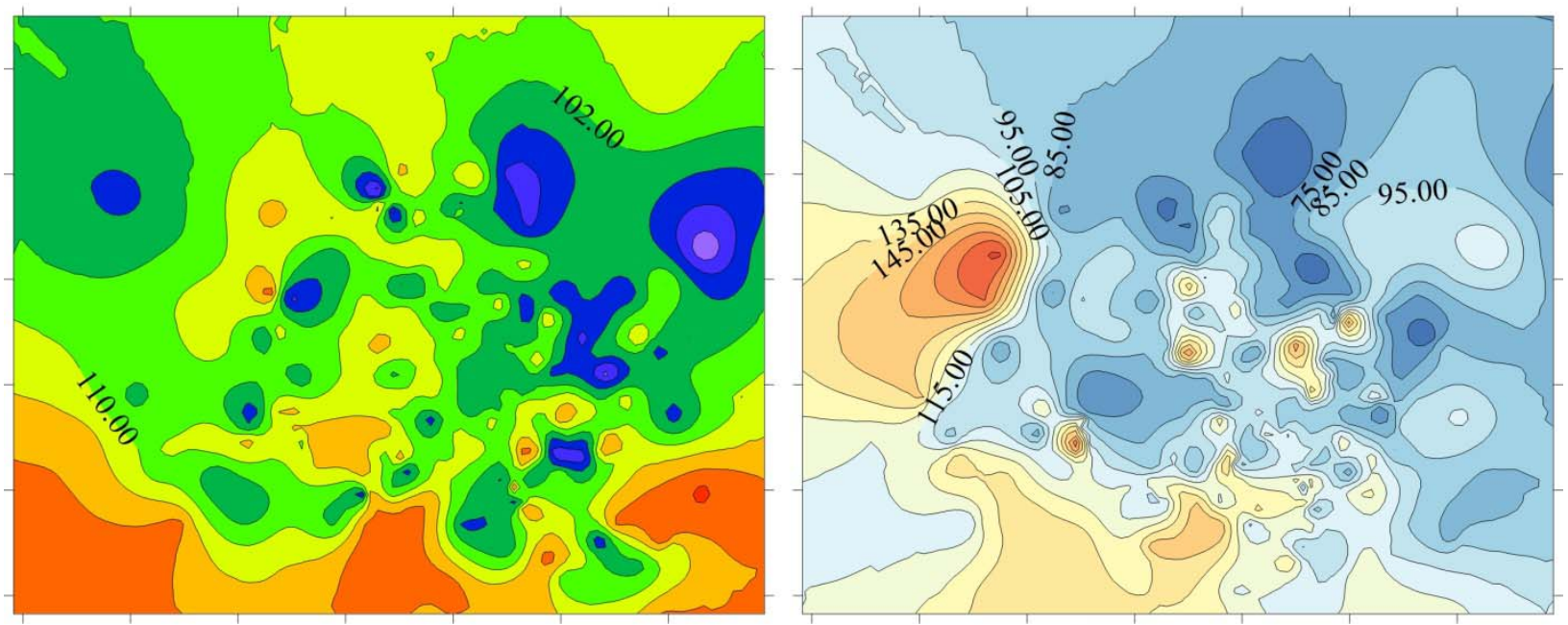

$\mathrm{N}$

$\mathrm{P}$

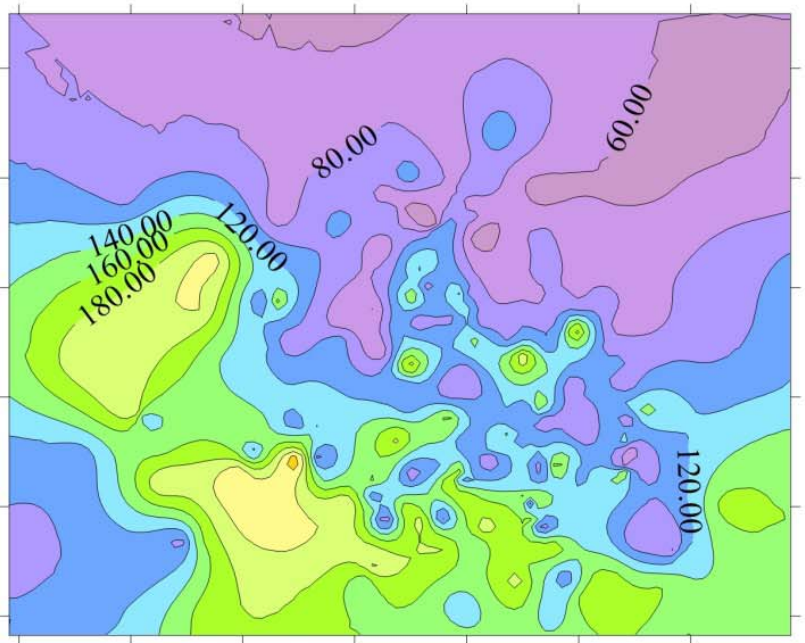

K

Рис. 2. Варіювання едафічних показників у просторі периих двох канонічних коренів

Умовні позначки: вісь абсцис - канонічна функція 1, вісь ординат - канонічна функція 2 . 


\section{СТОРІНКА МОЛОДОГО ВЧЕНОГО}

Канонічна функція 2 розрізняє кожну з перших груп на підгрупи з меншою глибиною оранки у парі (нульовий обробіток проти грунтозахисного та оранка на глибину 25-27 см проти чизелювання). У цьому разі більш глибокі варіанти оранки відрізняються більшими рівнями поживних речовин (азот, фосфор, калій).

Виділені полігони $є$ нічим іншим, як ареалами способів обробітку грунту в просторі дискримінантних функцій.

Значення канонічних змінних можуть також виступати як маркери осей простору, в межах якого можна показати мінливість едафічних показників i таким чином співставити категоріальні змінні способи механічного обробітку та континуальні змінні - едафічні показники (рис. 2).

Це можливо внаслідок того, що відповідний простір розподілений між способами механічного обробітку таким чином, що ці способи упорядковані (ординовані) у межах цього простору. Також слід ще раз зазначити, що цей простір володіє унікальною властивістю - границі у ньому між ареалами способів обробітку є прямими лініями.

Для всіх едафічних характеристик властива досить строката варіабельність у досліджуваному просторі канонічних функцій. Слід ще раз наголосити на специфічній властивості цього простору - лінійності границь між ареалами категоріальних станів системи. Це доволі контрастує зі вкрай варіабельною поведінкою континуальних едафічних змінних. Таку поведінку можна пояснити, якщо уявити ту обставину, що досліджені едафічні показники є маркерами складних та динамічних грунтотворних процесів, які мають переважно коливальну природу.

У цьому разі механічний обробіток виглядає як збурення, яке запускає множину коливальних процесів різної частоти та амплітуди. За такого підходу грунт, який зазнав впливу того чи іншого механічного обробітку, переходить не в один окремий стан, а трансформується до множини

\section{БІБЛІОГРАФІЯ}

1. Агрохімія: лабораторний практикум : навч. посібник / [під ред. Лісовала А. П.]. - К. : Вища школа, 1994. - С. 108-116.

2. Бараев А. И. О научных основах земледелия в степных районах / А. И. Бараев // Вестник с.-х. науки, 1976. - №4. - С. 22-35.

3. Бени А. В. Особенности обработки почвы на склонах северной лесостепи Западной Сибири / А. В. Бенц // Научно-технический бюлл. ВАСХНИЛ. - М., 1986. - №432. - С. 3-6.

4. Ершов В. А. Биологическая активность почвы динамічних станів, сукупність яких і характеризує той результат, який утворюється внаслідок обробітку.

\section{Висновки:}

1. Дискримінантний аналіз дає змогу класифікувати стани грунтової системи, які формуються внаслідок різних способів механічного обробітку за едафічними показниками. Для дискримінації чизелювання, безполицевої оранки, мінімального обробітку та «нульового обробітку» достатньо дві канонічні дискримінантні осі.

2. Канонічна функція 1 розділяє способи механічного обробітку з високою глибиною оранки (чизелювання на глибину $40 \mathrm{~cm}$ та оранка на глибину 25-27 см) від способів з малою глибиною та нульовим обробітком. Канонічна функція 2 розрізняє кожну з перших груп на підгрупи з меншою глибиною оранки у парі (нульовий обробіток проти грунтозахисного та оранка на глибину 25-27 см проти чизелювання). У цьому разі більш глибокі варіанти оранки відрізняються більшими рівнями поживних речовин (азот, фосфор, калій).

3. Значення канонічних змінних можуть також виступати як маркери осей простору, в межах якого можна показати мінливість едафічних показників та таким чином співставити категоріальні змінні - способи механічного обробітку та континуальні змінні - едафічні показники. Для всіх едафічних характеристик властива доволі строката варіабельність у досліджуваному просторі канонічних функцій.

4. Одержані результати можна пояснити, виходячи 3 того, що механічний обробіток виглядає як збурення, яке запускає множину коливальних процесів різної частоти та амплітуди. За такого підходу грунт, який зазнав впливу того чи іншого механічного обробітку, переходить не в один окремий стан, а трансформується до множини динамічних станів, сукупність яких і характеризує той результат, який утворюється внаслідок обробітку у відповідний період часу.

при длительном предшествующем применении минимальной обработки / В. А. Ершов // Земледелие. - 1991. - №2. - С. 34-36.

5. Жуков О. В. Екоморфічний аналіз консорцій грунтових тварин / О. В. Жуков. - Дніпропетровськ : вид-во «Свідлер А. Л.». - 2009. - 239 с.

6. Качинский Н. А. Физика почвы / Н. А. Качинский. - М. : Высшая школа, 1965. - Ч. 1. C. 75-79.

7. Ким Д. О. Факторный, дискриминантный и кластерный анализ / Д. О. Ким, Ч. У. Мьюлер. - 
М. : Финансы и статистика. - 1989. - С. 5-77.

8. Медведев B. B. Структура почвы /

В. В. Медведев. - Харьков, 2008. - 406 с.

9. Метелев В. Я. Особенности обработки почвы под яровую пшеницу на Алтае / В. Я. Метелев, П. И. Талышев // Земледелие. - 1979. - №7. C. 25-28.

10. Немцев С. Н. Агроэкологическая эффективность почвозащитных технологий на склоновых землях Ульяновской области / С. Н. Немцев : автореф. дис. на здобуття наук. ступеня к.с.-Х.н. Кинель, 1996. - 27 с.

11. Onара M. M. Родючість грунтів і енергозбереження в землеробстві / М. М. Опара, П. П. Ярошенко. - Полтава, 2006. - 62 с.

12. Влияние агротехнических приемов на микробиологические процессы трансформации гумуса в мощном черноземе левобережной лесостепи Украины / [Ромейко И. Н., Битюкова Л. Б., Плишко М. К., Зиль Л. М.] // Бюллетень ВНИИСХМ. - 1988. - №49. - С. 30-36.

13. Семешкина П. С. Способы основной обработки серой лесной почвы / П. С. Семешкина // Земледелие. - 1994. - №5. - С. 24.

14. Силиченков Г.В. Совершенствование обработки почвы в Белоруссии / Г.В.Силиченков // Земледелие. - 1991. - №4. - С. 45-47.

15. Сираев М. Г. Совершенствование минимальной обработки почвы в степи Башкортостана / М. Г. Сираев // Земледелие. - 1997. - №8. C. 27-28.

16. Биологическая активность чернозема выщелоченного юго-западной Сибири в зависимости от обработки / [Слесарев В. Н., Святская Л. Н., Хамова О. Ф., Щитов А. Г.] // Почвоведение. -
1987. - №4. - С. 137-142.

17. Таланов И. П. Эффективность плоскорезной обработки почвы / И. П. Таланов // Земледелие. - 1995. - №8. - С. 13.

18. Тихомирова А. Д. Изменение микрофлоры и ферментативной активности почвы в связи с разной периодичностью оборачивания пахотного слоя : сборник научных трудов / Тихомирова А. Д., Гамзикова О. И. // Вопросы численности, биомассы и продуктивности почвенных микроорганизмов. - Л. : Наука, 1972. - С. 258-265.

19. Ульченко В. Я. Минимализация обработки почвы в зернопаровых севооборотах / В. Я. Ульченко // Земледелие. - 1992. - №6. - С. 23.

20. Хабирахвганов X. Х. Обработка почвы под яровую пшеницу и горох в Татарстане / Х. Х. Хабирахвганов, И. Г. Гайнзадинов // Земледелие. - 1993. - №8. - С. 20.

21. Чепрасов A. A. Влияние систем основной обработки почвы на биологическую активность и агрохимические свойства чернозема выщелоченного лесостепи Приобья при разном уровне интенсификации / А. А. Чепрасов // Сиб. Вестник с.-х. науки. - 1999. - №1, 2. - С. 8-13.

22. Шевченко М. В. Наукові основи систем обробітку грунту в польових сівозмінах Лівобережного Лісостепу України : дис. ... д.с.-г.н. : 06.01.01 «Загальне землеробство»/ М. В. Шевченко. - Харків, 2015. - 539 с.

23. Ярошенко П. П. Мінімальний обробіток грунту - основа екологічного землеробства / П. П. Ярошенко, М. В. Іванюта // Конструювання, виробництво та експлуатація сільськогосподарських машин (фахове видання). - Вип. 34. - Кіровоград, 2004. - С. 36. 